Pharmaceutical Biology

\title{
Evaluation of Biological Activity of Turkish Plants. Rapid Screening for the Antimicrobial, Antioxidant, and Acetylcholinesterase Inhibitory Potential by TLC Bioautographic Methods
}

\section{Deniz Tasdemir, Ali Dönmez, Ihsan Çalıs \& Peter Rüedi}

To cite this article: Deniz Tasdemir, Ali Dönmez, Ihsan Çalıs \& Peter Rüedi (2004) Evaluation of Biological Activity of Turkish Plants. Rapid Screening for the Antimicrobial, Antioxidant, and Acetylcholinesterase Inhibitory Potential by TLC Bioautographic Methods, Pharmaceutical Biology, 42:4-5, 374-383, DOI: $10.1080 / 13880200490519695$

To link to this article: https://doi.org/10.1080/13880200490519695

曲 Published online: 29 Sep 2008.

Submit your article to this journal $₫$

Llll Article views: 203

Q View related articles ¿

Citing articles: 15 View citing articles 주 


\title{
Evaluation of Biological Activity of Turkish Plants. Rapid
}

\section{Screening for the Antimicrobial, Antioxidant, and}

\section{Acetylcholinesterase Inhibitory Potential by TLC}

\section{Bioautographic Methods}

\author{
Deniz Tasdemir ${ }^{1}$, Ali A. Dönmez ${ }^{2}$, Ihsan Çalıs ${ }^{3}$ and Peter Rüedi ${ }^{1}$ \\ ${ }^{1}$ Institute of Organic Chemistry, University of Zurich, Zurich, Switzerland; ${ }^{2}$ Department of Biology, Faculty of Science, \\ Hacettepe University, Ankara, Turkey; ${ }^{3}$ Department of Pharmacognosy, Faculty of Pharmacy, Hacettepe University, Ankara, \\ Turkey
}

\begin{abstract}
Using thin-layer chromatography (TLC) bioautography, a total of 58 extracts from various organs (aerial parts, leaves, flowers, fruits, roots) of 16 Turkish plants were tested for their antibacterial, antifungal, acetylcholinesterase inhibitory, antioxidant, and radical scavenging activities. The hexane, $\mathrm{CHCl}_{3} / \mathrm{CH}_{2} \mathrm{Cl}_{2}$, water, and total $\mathrm{MeOH}$ extracts were used. No activity was observed against two Gram-negative bacteria (Escherichia coli and Pseudomonas aureginosa) and the yeast Candida albicans. However, 23 plant extracts, mostly the $\mathrm{CHCl}_{3} / \mathrm{CH}_{2} \mathrm{Cl}_{2}$ and $\mathrm{H}_{2} \mathrm{O}$-solubles, inhibited the growth of all five Gram-positive bacteria tested, Micrococcus luteus, Bacillus subtilis, Bacillus cereus, Staphylococcus aureus, and Staphylococcus epidermidis. Of the active extracts, the $\mathrm{CHCl}_{3}$-soluble of the roots of Putoria calabrica (L. fil) DC (Rubiaceae) displayed the highest antibacterial potential. The majority of the $\mathrm{CHCl}_{3} / \mathrm{CH}_{2} \mathrm{Cl}_{2}$ crude extracts also appeared to inhibit acetylcholinesterase on TLC plates at $100 \mu \mathrm{g} / \mathrm{spot}$ concentration. Particularly active samples were the middle polarity extracts $\left(\mathrm{CHCl}_{3} / \mathrm{CH}_{2} \mathrm{Cl}_{2}\right)$ of the leaves of Rhododendron smirnovii Trautv., $R$. ponticum L., and $R$. ungernii Trautv. (Ericaceae). $\beta$-Carotene, $\beta$ carotene/linoleic acid mixture, and 2,2-diphenyl-1-pieryhydrazyl (DPPH) solutions sprayed onto TLC plates were used for detecting antioxidant and radical scavenging properties of the crude extracts. Antioxidant and radical scavenging activities were found to be predominant in highly polar
\end{abstract}

extracts. The water-solubles of all Rhododendron (Ericaceae) and Phlomis (Lamiaceae) species presented the most significant activity.

Keywords: Acetylcholinesterase inhibitor, antibacterial, antifungal, antioxidant, radical scavenger, Turkish plants.

\section{Introduction}

Turkey joins two continents, Europe and Asia, through Asia Minor. Due to this geographical position, Turkey serves as a biological bridge in the migration of species. For example, Turkish flora comprises 9300 plant species, 3000 of which are endemic (Davis, 1965-1988; Güner et al., 2000), rendering it to be one of the most extensive floras in continental Europe (Sezik et al., 1991). The strategic position has also allowed the combination of both Western and Eastern cultures and the development of a rich body of knowledge of traditional medicinal plants. Despite the accessibility of Western medicine, many people, particularly poor sections and remote villagers, still rely on phytomedicines, at least for preliminary treatments or simple diseases (Honda et al., 1996). Systematic surveys concerning the medicinal use of Turkish plants have emerged (Yesilada et al., 1995, 1999; Tuzlacı \& Aymaz, 2001). Several screening studies

Accepted: March 10, 2004

Address correspondence to: D. Tasdemir, Institute of Organic Chemistry, University of Zurich, Winterthurerstrasse 190, CH-8057, Zurich, Switzerland. E-mail: dtasdemir@hotmail.com 
on Turkish medicinal plants are also available in the literature (Ahmad et al., 1993; Sener, 1994; Sökmen et al., 1999).

In order to discover biologically active chemicals, naturalproduct research employs a number of relevant bioassays. These assays serve for detection, for monitoring the chemical fractionation/purification procedures, and for preliminary biological characterization of pure compounds (Claeson \& Bohlin, 1997). Generally, multiple screening methods are used in natural-product drug discovery programs, as screenings with a narrow testing base have failed in the past. For the initial screening of crude extracts, simple, rapid, inexpensive bioassays with good reproducibility are needed. These simple-to-perform assays generally require a small amount of sample. One such method is thin-layer chromatography (TLC) bioautography, which possesses good compatibility with the large numbers of samples to be tested (Hamburger $\&$ Hostettmann, 1991). It gives very quick access for detection and localization of the active chemicals in a complex plant extract. Using this method, 58 crude extracts obtained from 22 various anatomical parts of 16 Turkish plants were screened for their antimicrobial, acetylcholinesterase inhibitory, antioxidant, and radical scavenging activities. Some of these plants are used in traditional medicine and/or are important for public health. For example, mad honey poisoning, which is due to grayanatoxins in honey produced from the nectar of Rhododendron ponticum L. flowers is known from ancient times (Baytop, 1984). It is still one of the common food intoxications encountered for humans and livestock in Turkey (Baytop, 1984; Onat et al., 1991; Sütlüpınar et al., 1993). Despite this, $R$. ponticum is widely used as an analgesic in northern Anatolia for the treatment of rheumatic or dental pain, common colds, and edema, both internally and externally (Baytop, 1984; Yesilada et al., 1999). Leonurus cardiaca L. is consumed for its cardiotonic, expectorant, and euphoric effects as well as to induce constipation (Baytop, 1984). The herbal tea called Salba (or mountain tea) prepared from many naturally growing Phlomis sp. is known in Turkish folk medicine for its stomachic, tonic, analgesic, and antipyretic effects (Baytop, 1984; Koçak \& Özhatay, 2000; Yesilada, 2002). Wendlandia ligustroides L. is a new generic record for Turkish flora (Dönmez, 2002) and we are aware of no traditional use of this plant. However, some other Wendlandia sp. are used against dysentery, fever, diarrhea, ulcers, and rheumatism in Far Eastern countries (Jayasinghe et al., 2002). Several members of the genus Scrophularia find use as herbal remedy, both internally and externally, for their antiseptic and digestive properties (Sezik et al., 2001). To our knowledge, there is no record for the folkloric use of two endemic Scrophularia species (S. cryptophila Boiss ex Heldr. and S. lepidota Boiss) investigated in the current study. Urtica sp. have gained a fair deal of popularity in Turkish folk medicine, particularly in recent years, in the treatment of a wide range of diseases, such as cancer, hemorrhoids, and rheuma (Yesilada et al., 1995, 1999).

The main goal of the current study is the multiple screening of some recorded and unrecorded Turkish plants, particu- larly those endemic to the Turkish flora, in different benchtop bioassays. This paper presents a high potential of different activities of some well-known Turkish medicinal plants and also introduces new plant sources whose biological activities have not been documented before.

\section{Materials and Methods}

\section{Plant material}

Plant materials were collected from different sites of Turkey and identified by one of us (A.A.D.). Voucher specimens were deposited at HUB, Department of Biology (Faculty of Science) and/or Herbarium of Department of Pharmacognosy (Faculty of Pharmacy) of Hacettepe University. Table 1 shows the names of the plants investigated, their families, the voucher numbers, and the parts used.

\section{Extraction and partition}

The types of extracts prepared for testing are also illustrated in Table 1. Shadow-dried plant material (10-200g dry weight) was ground and extracted three-times with $\mathrm{MeOH}$. The solvent was removed under reduced pressure at $30^{\circ} \mathrm{C}$. The crude extracts were partitioned by a modified Kupchan (1973) protocol: The extracts were dissolved in $90 \% \mathrm{MeOH}$ in water and extracted with hexane (extract no. 1). The concentration of the aqueous $\mathrm{MeOH}$ was adjusted to $30 \%$ by the addition of water (extract no. 3), before partitioning against $\mathrm{CHCl}_{3}$ (extract no. 2a) or $\mathrm{CH}_{2} \mathrm{Cl}_{2}$ (extract no. 2b). Due to very low amount of material, the $\mathrm{MeOH}$ extract of the flowers of three Rhododendron species, $R$. ponticum L. R. luteum Sweet, and $R$. ungernii Trautv. were partitioned between water and $\mathrm{CH}_{2} \mathrm{Cl}_{2}$, while the total $\mathrm{MeOH}$ extracts of both aerial parts and roots of Asperula nitida subsp. subcapitellata Sibth ex SM were partitioned between water and hexane. The aerial parts of Urtica sp. urtica dioica were extracted with both hot water (as consumed in the folk medicine, extract no. $4 \mathrm{~b}$ ) and $\mathrm{MeOH}$ (extract no. 4a) prior to testing. Also, the total $\mathrm{MeOH}$ extract of the roots of Scrophularia lepidota Boiss (SLR-4b) was tested directly without any further partition procedure.

\section{Thin-layer chromatography}

Aluminum-backed silica gel $60 \mathrm{~F}_{254}$ plates (Merck, Darmstadt) were used for all bioautographic methods. In the antimicrobial assay, extracts were directly deposited (as spots) on the TLC plates. In all other autobioautographic assays, the spotted extracts were developed in the following solvent sytems prior to testing: hexane: $\operatorname{EtOAc}(3: 1)$ (hexane extracts); $\mathrm{CHCl}_{3}: \mathrm{MeOH}(9: 1) \quad\left(\mathrm{CHCl}_{3} / \mathrm{CH}_{2} \mathrm{Cl}_{2}\right.$ extracts); $\mathrm{CHCl}_{3}: \mathrm{MeOH}: \mathrm{H}_{2} \mathrm{O}(7: 3: 0.2)\left(\mathrm{H}_{2} \mathrm{O}\right.$ and crude $\mathrm{H}_{2} \mathrm{O} / \mathrm{MeOH}$ extracts). Two plates were developed for each assay, one for biological test and the second as a reference, detected with vanillin $/ \mathrm{H}_{2} \mathrm{SO}_{4}$ reagent. 
Table 1. Turkish plants tested for biological activities.

\begin{tabular}{|c|c|c|c|c|}
\hline Family & Plant species & Part(s) used & Voucher no & Extracts tested \\
\hline \multirow{7}{*}{ Ericaceae } & \multirow[t]{2}{*}{ Rhododendron ponticum $\mathrm{L}$. } & Leaves (RPL) & \multirow[t]{2}{*}{ AAD9881 } & $1,2 \mathrm{a}, 3$ \\
\hline & & Flowers (RPF) & & $2 b, 3$ \\
\hline & \multirow[t]{2}{*}{ Rhododendron luteum Sweet } & Leaves (RLL) & \multirow[t]{2}{*}{ AAD9882 } & $1,2 b, 3$ \\
\hline & & Flowers (RLF) & & $2 b, 3$ \\
\hline & Rhododendron $\times$ sochadzeae Charadze \& & Leaves (RSoL) & AAD9892 & $1,2 b, 3$ \\
\hline & Rhododendron ungernii Trautv. & Flowers (RUF) & AAD9880 & $2 b, 3$ \\
\hline & Rhododendron smirnovii Trautv.* & Leaves (RSL) & AAD9889 & $1,2 b, 3$ \\
\hline \multirow[t]{4}{*}{ Lamiaceae } & Leonurus cardiaca $\mathrm{L}$. & Aerial (LC) & HUEF91140 & $1,2 \mathrm{a}, 3$ \\
\hline & Phlomis leucophracta P.H.Davis \& Hub.-Mor.* & Aerial (PL) & HUEF00023 & $1,2 \mathrm{a}, 3$ \\
\hline & Phlomis kurdica Rech. fil & Aerial (PK) & AAD7820 & $1,2 \mathrm{a}, 3$ \\
\hline & Phlomis russeliana (Sims) Bentham* & Aerial (PR) & HUEF92101 & $1,2 \mathrm{a}, 3$ \\
\hline & Putoria calabrica (L. fil) DC & Roots (PCR) & AAD9930 & $1,2 \mathrm{a}, 3$ \\
\hline & Wendlandia ligustroides L. & Aerial (WL) & AAD9749 & $1,2 \mathrm{a}, 3$ \\
\hline \multirow[t]{3}{*}{ Scrophulariaceae } & Scrophularia cryptophila Boiss \& Heldr.* & Aerial (SC) & AAD8958 & $1,2 \mathrm{a}, 3$ \\
\hline & \multirow[t]{2}{*}{ Scrophularia lepidota Boiss * } & Aerial (SL) & AAD9606 & $1,2 \mathrm{a}, 3$ \\
\hline & & Roots (SLR) & & $4 b$ \\
\hline Urticaceae & Urtica dioica $\mathrm{L}$. & Aerial (UD) & AAD11164 & $4 a, 4 b$ \\
\hline
\end{tabular}

*: endemic for Turkish flora; 1: hexane extract; 2a: $\mathrm{CHCl}_{3}$ extract; $2 \mathrm{~b}: \mathrm{CH}_{2} \mathrm{Cl}_{2}$ extract; 3: $\mathrm{H}_{2} \mathrm{O}$ extract; $4 \mathrm{a}$ : total $\mathrm{H}_{2} \mathrm{O}$ extract; $4 \mathrm{~b}$ : total MeOH extract. The code numbers are abbreviated from the plant name and the plant organ used.

\section{Antimicrobial assay by the agar overlay method}

Eight microorganisms, seven bacteria [Micrococcus luteus (ATCC-9341), Bacillus subtilis (ATCC-6633), Bacillus cereus (ATCC-10702), Staphylococcus aureus (ATCC-25923), Staphylococcus epidermidis (ATCC-12228), Escherichia coli (ATCC-25922), Pseudomonas aeruginosa (ATCC-27853)] and a yeast [Candida albicans (ATCC-25790)] were used for testing. Müller Hinton Agar (Oxoid, Wesel) and Malt Extract Agar (Oxoid, Wesel) were used as solid media for the agar overlay of bacteria and fungus, respectively. Inocula were prepared by suspending the microorganism in $10 \mathrm{ml}$ of Nutrient Broth (Oxoid, for bacteria) and Saboraud Liquid Medium (Oxoid, for C. albicans) and incubating it overnight at $37^{\circ} \mathrm{C}$. The final concentration of the microorganism was approximately $10^{6}$ cell $/ \mathrm{ml}$. Plant extracts $(200 \mu \mathrm{g})$ were directly deposited on the TLC plates (the diameter of the spot is maximum $4 \mathrm{~mm}$ ) and then placed in a square sterile Petri dish $(10 \times 10 \mathrm{~cm})$. Microorganism suspension $(50 \mu \mathrm{l})$ and $10 \mathrm{ml}$ of solid media were mixed (Vortex, Zurich) and homogeneously applied on these TLC plates. Solidified plates were incubated at $37^{\circ} \mathrm{C}$ for $16-20 \mathrm{~h}$ and sprayed with an aqueous solution of thiazolyl blue tetrazolium bromide (Fluka, Buchs $2.5 \mathrm{mg} / \mathrm{ml}$ ) and further incubated at $37^{\circ} \mathrm{C}$, if necessary. Biological activity was observed as clear inhibition zones against a purple background. Different concentrations of chloramphenicol (Siegfried, Zofingen) and miconazole (Sigma, Steinheim) were used as positive controls.

\section{Inhibition of bleaching of $\beta$-carotene (BBC)}

Crude extracts $(100 \mu \mathrm{g})$ were deposited on TLC plates and eluted in suitable solvent system mixtures mentioned above. Completely dried TLC plates were sprayed with an $0.05 \%$ solution of $\beta$-carotene (Fluka) in $\mathrm{CHCl}_{3}$ and left at room temperature for $12 \mathrm{~h}$ until decoloration of the background. Active compounds remained as yellow-orange spots on a white background (Sánchez-Medina et al., 2001). Ascorbic and caffeic acids (5 and $10 \mu \mathrm{g} / \mathrm{spot}$ ) were used as positive controls. All experiments were carried out in duplicate.

\section{Inhibition of bleaching of $\boldsymbol{\beta}$-carotene induced by autooxidation of linoleic acid (BBCLA)}

Each extract $(100 \mu \mathrm{g})$ was applied on TLC plates and developed in a suitable solvent system. After migration of the sample, the plate was thoroughly dried by means of a hair dryer and sprayed with the mixture of linoleic acid (Fluka, 2 drops $)$ in $\mathrm{EtOH}(60 \mathrm{ml})$ and $\beta$-carotene $(12 \mathrm{mg})$ in $\mathrm{CHCl}_{3}$ $(30 \mathrm{ml})$. Orange spots remained after exposing the plate to sunlight, indicative of antioxidant activity (Whittern et al., 1984). Ascorbic and caffeic acids (5 and $10 \mu \mathrm{g} / \mathrm{spot}$ ) were used as positive controls. All experiments were carried out in duplicate. 


\section{Reduction of DPPH radical}

The extracts $(100 \mu \mathrm{g})$ were spotted on silica TLC plates. After developing with one of the aforementioned solvent systems, plates were sprayed with a methanolic solution of 2,2diphenyl-1-picrylhydrazyl radical (DPPH, 0.2\%, Fluka) and left at room temperature for $30 \mathrm{~min}$. Antiradical activity was observed as white-yellow spots on a purple background (Cuendet et al., 1997). Ascorbic and caffeic acids (5 and 10 $\mu \mathrm{g} / \mathrm{spot}$ ) were used as positive controls. All experiments were carried out in duplicate.

\section{Acetylcholinesterase (AChE) inhibitory potential}

Marston et al. (2002) recently reported the procedure for this bioassay. Briefly, AChE (Sigma, product no. C2888, 1000 U) was dissolved in Tris- $\mathrm{HCl}$ buffer ( $\mathrm{pH}$ 7.8) and stabilized by addition of bovine serum enzyme (Merck, product no. $102606,150 \mathrm{mg}$ ). TLC plates were prepurified by developing with acetone prior to the application of the extracts $(100 \mu \mathrm{g})$ and galantamine (Sigma, $2 \mu \mathrm{g} / \mathrm{spot}$ ), which was used as positive control. Eluted TLC plates were completely dried and sprayed with enzyme solution, followed by incubation at $37^{\circ} \mathrm{C}$ for $20 \mathrm{~min}$ (humid atmosphere). Enzyme activity was detected by spraying the ethanolic solution of 1-naphtyl acetate $(2.5 \%)$ and the aqueous solution of Fast Blue B salt $(0.25 \%)$. Potential AChE inhibitors were appeared as clear zones on a purple-colored background.

\section{Results}

The crude extracts of 16 plants found in Turkey were subjected to different autobiographic assays. Tables 1-4 display the extracts found to be active in these test methods. To facilitate the evaluation of antioxidant/radical scavenging and AChE inhibitory activities, the developed chromatograms were divided in three polarity zones, high $\left(\mathrm{R}_{\mathrm{f}} 0-0.33\right)$, medium $\left(\mathrm{R}_{\mathrm{f}} 0.34-0.66\right)$, and low $\left(\mathrm{R}_{\mathrm{f}} 0.67-1.0\right)$.

None of the plant extracts showed antimicrobial activity against Gram-negative bacteria, namely E. coli and P. aeruginosa or the yeast, C. albicans, at $200 \mu \mathrm{g} /$ spot concentration. Among 58 extracts tested, 48 crude extracts (83\%) were found to possess activity against one or more remaining Gram-positive test bacteria, M. luteus, B. subtilis, B. cereus, $S$. aureus, and $S$. epidermidis. Twenty-three plant extracts (40\%) showed a wide antibiotic spectrum, being active against all five Gram-positive bacteria. The most active extracts were the $\mathrm{CHCl}_{3} / \mathrm{CH}_{2} \mathrm{Cl}_{2}$-solubles, followed by the water-solubles. Of all $17 \mathrm{CHCl}_{3} / \mathrm{CH}_{2} \mathrm{Cl}_{2}$ extracts, 14 were active against all five strains. Seven $\mathrm{H}_{2} \mathrm{O}$ extracts, including 5 Rhododendron (RLF-3, RSoL-3, RSoFr-3, RUL-3, RSL-3) and two Asperula extracts (AN-3, ANR-3), one hexane extract (ANR-1), and the total $\mathrm{MeOH}$ extract of the roots of Scrophularia lepidota (SLR-4b) also inhibited the growth of all five bacteria (Table 2). Overall, the most prominent antibacterial potential was detected with the $\mathrm{CHCl}_{3}$-solubles of the roots of Putoria calabrica (PCR-2a) that displayed inhibition zones over $10 \mathrm{~mm}$ toward all Gram-positive bacteria. Water extracts of RPL, RLL, RUF, RPF, and WL inhibited the growth of the above-mentioned bacterial strains, except for B. subtilis. Seven hexane extracts (LC-1, PK-1, PL-1, PR-1, MP-1, AN-1, PCR-1) and one $\mathrm{CHCl}_{3}$ extract (SL-2a) were found to be active against three bacteria. Five crude extracts (RSoL-1, RSoFr-1, RUF-2b, WL-2a, PL-3) showed weak to moderate activity (inhibition zone 4-7 mm) toward two bacterial species, whereas seven plant extracts indicated in Table 2 inhibited just one strain. S. aureus appeared to be the most sensitive species in this study, as 40 extracts showed activity against this strain. On the other hand, the highest potency (the largest inhibition zones) was observed toward M. luteus.

The results obtained for antioxidant/radical scavenging activities are summarized in Table 3. In the first assay (BBC), the extracts that prevented oxidation of $\beta$-carotene and persisted its yellow-orange color on TLC plate were considered as antioxidants. The second method (BBCLA) used a model lipid substrate (linoleic acid) and is based on the loss of yellow color of $\beta$-carotene due to its reaction with radicals formed by air oxidation (autooxidation) of linoleic acid (Koleva et al., 2002). These two methods gave similar, but not identical results. The DPPH method is based on the reduction of the stable $\mathrm{DPPH}^{*}$ radical that absorbs at $515 \mathrm{~nm}$ in alcohol solution. In the presence of a hydrogen-donating antioxidant/radical scavenger, the absorption disappears due to the formation of the nonradical form (DPPH-H). DPPH assay also produced parallel results, but a larger number of extracts with a higher number of active metabolites scavenged the DPPH radical to appear as white to yellow spots on the purple background.

Among 17 hexane extracts, ANR-1 showed the highest activity in the first two antioxidant assays (BBC and BBCLA) in both high $\left(\mathrm{R}_{\mathrm{f}} 0-0.33\right)$ and medium polarity $\left(\mathrm{R}_{\mathrm{f}} 0.34-0.66\right)$ regions of the TLC plate. In the DPPH assay, the same extract, plus RSoFr-1 and PCR-1, exhibited strong active spots in all three polarity regions. It is noteworthy that many hexane extracts bleached the DPPH radical at the very top of the TLC plate (front), which is a typical region for chlorophylls, carotenoids, or fatty acids (Table 3 ).

In $\beta$-carotene assays, the majority of the $\mathrm{CHCl}_{3} / \mathrm{CH}_{2} \mathrm{Cl}_{2}$ extracts showed also one or two weakly active spots, mostly in high and medium $\mathrm{R}_{\mathrm{f}}$ regions. We noted that almost all Rhododendron extracts retained a reasonably strong yellow spot around $R_{f}$ 0.4. DPPH reagent produced more active spots, and the strongest activity was observed in the low $\mathrm{R}_{\mathrm{f}}$ region $(0-0.33)$. The most noticeable activity in the middle polarity region was exerted by MP-2b and PCR-2a extracts, whereas the $\mathrm{CH}_{2} \mathrm{Cl}_{2}$-solubles of the Rhododendron flower and fruit extracts (RLF-2b, RPF-2b, RUF-2b, RSoFr-2b) had distinguished activity at the top of the TLC plate.

The highest antioxidant/radical scavenger potential was detected in the water extracts. Activity was exerted by highly polar phytochemicals with $R_{\mathrm{f}}$ values between 0 and 0.5 . All 
D. Tasdemir et al.

Table 2. Extracts displaying antimicrobial activity (diameters of inhibition zones in $\mathrm{mm}$ ).

\begin{tabular}{|c|c|c|c|c|c|}
\hline Plant extract & M. luteus & B. subtilis & B. cereus & S. aureus & S. epidermidis \\
\hline RLL-1 & - & - & - & 5 & - \\
\hline RSoL-1 & - & 5 & - & 4.5 & - \\
\hline RSoFr-1 & - & 5 & - & 4 & - \\
\hline RUL-1 & - & - & - & 4 & - \\
\hline LC-1 & - & 5 & 5 & 5 & - \\
\hline PL-1 & - & 4 & 4 & 6 & - \\
\hline PK-1 & 6 & - & 4 & 5 & - \\
\hline PR-1 & - & 4 & 4 & 6 & - \\
\hline MP-1 & - & 5 & 4 & 5 & - \\
\hline AN-1 & - & 4 & 4 & 4.5 & - \\
\hline ANR-1 & 5 & 5 & 5 & 5 & 5 \\
\hline PCR-1 & - & 5 & 5 & 4 & - \\
\hline WL-1 & - & - & 4 & - & - \\
\hline SL-1 & - & 4 & - & - & - \\
\hline RPL-2a & 12 & 6 & 7 & 6 & 5 \\
\hline RPF-2b & 11 & 5 & 7 & 11 & 10 \\
\hline RLL-2b & 10 & 5 & 6 & 5 & 5 \\
\hline RSoL-2b & 12 & 7 & 8 & 9 & 10 \\
\hline RSoFr-2b & 8 & 5 & 5 & 5 & 4 \\
\hline RUL-2b & 7 & 6 & 7 & 7 & 5 \\
\hline RUF-2b & 5 & - & - & 7 & - \\
\hline RSL-2b & 7 & 5 & 5 & 6 & 5 \\
\hline LC-2a & 12 & 6 & 6 & 6 & 5 \\
\hline PL-2a & 10 & 7 & 7 & 7 & 7 \\
\hline PK-2a & 10 & 5 & 6 & 6 & 5 \\
\hline PR-2a & 10 & 6 & 7 & 7 & 5 \\
\hline MP-2b & 10 & 6 & 6 & 6 & 5 \\
\hline PCR-2a & 15 & 11 & 11 & 12 & 11 \\
\hline WL-2a & 5 & - & 5 & - & - \\
\hline $\mathrm{SC}-2 \mathrm{a}$ & 6 & 5 & 5 & 5 & 5 \\
\hline SL-2a & 6 & 6 & 6 & - & - \\
\hline RPL-3 & 13 & - & 10 & 6 & 6 \\
\hline RPF-3 & 8 & - & 8 & 6 & 6 \\
\hline RLL-3 & 15 & - & 10 & 6 & 6 \\
\hline RLF-3 & 10 & 11 & 8 & 6 & 6 \\
\hline RSoL-3 & 9 & 7 & 9 & 9 & 9 \\
\hline RSoFr-3 & 11 & 6 & 11 & 10 & 7 \\
\hline RUL-3 & 13 & 6 & 10 & 9 & 7 \\
\hline RUF-3 & 12 & - & 9 & 7 & 6 \\
\hline RSL-3 & 15 & 5 & 9 & 9 & 9 \\
\hline PL-3 & 7 & - & 5 & - & - \\
\hline MP-3 & 5 & - & - & - & - \\
\hline AN-3 & 6 & 6 & 6 & 6 & 5 \\
\hline ANR-3 & 10 & 10 & 7 & 9 & 7 \\
\hline PCR-3 & 4 & - & - & - & - \\
\hline WL-3 & 11 & - & 9 & 6 & 6 \\
\hline SLR-4b & 8 & 6 & 6 & 5 & 6 \\
\hline UD-4b & - & - & - & - & 6 \\
\hline Chloramphenicol $^{\mathrm{a}}$ & 9 & 6 & 5 & 5 & 7 \\
\hline
\end{tabular}

For abbreviations see Table 1.

${ }^{a}$ Applied concentration of chloramphenicol is $0.1 \mu \mathrm{g} / \mathrm{spot}$. 
Table 3. Antioxidant and radical scavenging plant extracts.

\begin{tabular}{|c|c|c|c|c|c|c|c|c|c|}
\hline \multirow[b]{2}{*}{ Extract } & \multicolumn{3}{|c|}{$\mathrm{R}_{\mathrm{f}} 0-0.33$} & \multicolumn{3}{|c|}{$R_{f} 0.34-0.66$} & \multicolumn{3}{|c|}{$\mathrm{R}_{\mathrm{f}} 0.67-1.0$} \\
\hline & $\beta$-Carotene & $\begin{array}{l}\beta \text {-Carotene/ } \\
\text { linoleic acid }\end{array}$ & DPPH & $\beta$-Carotene & $\begin{array}{l}\beta \text {-Carotene/ } \\
\text { linoleic acid }\end{array}$ & DPPH & $\beta$-Carotene & $\begin{array}{c}\beta \text {-Carotene/ } \\
\text { linoleic acid }\end{array}$ & DPPH \\
\hline RPL-1 & - & - & - & - & - & - & - & - & ++ \\
\hline RLL-1 & - & - & - & - & - & ++ & - & - & ++ \\
\hline RSoL-1 & - & - & - & - & - & + & & - & + \\
\hline RSL-1 & - & - & + & - & - & + & - & - & ++ \\
\hline LC-1 & - & - & + & - & - & + & - & - & ++ \\
\hline PL-1 & - & - & + & - & - & + & - & - & + \\
\hline PK-1 & - & - & - & - & - & + & - & - & + \\
\hline PR-1 & - & - & + & - & - & + & - & - & + \\
\hline MP-1 & - & - & + & - & - & - & - & - & + \\
\hline AN-1 & - & - & - & - & - & + & - & - & + \\
\hline SL-1 & - & - & + & - & - & ++ & - & - & ++ \\
\hline RPL-2a & ++ & - & +++ & - & - & + & - & - & - \\
\hline RPF-2b & + & - & ++ & + & + & + & + & - & ++ \\
\hline RLL-2b & + & - & ++ & + & ++ & ++ & + & - & - \\
\hline RLF-2b & - & - & ++ & + & - & + & ++ & - & + \\
\hline RSoL-2b & ++ & ++ & +++ & + & - & - & - & - & - \\
\hline RSoFr-2b & + & - & ++ & + & + & + & - & - & + \\
\hline RUL-2b & ++ & - & ++ & + & + & ++ & - & - & - \\
\hline RUF-2b & + & - & + & ++ & - & ++ & - & - & + \\
\hline RSL-2b & ++ & + & +++ & + & - & ++ & - & - & - \\
\hline LC-2a & + & ++ & ++ & + & + & ++ & - & - & - \\
\hline PL-2a & ++ & ++ & +++ & - & - & ++ & - & - & - \\
\hline PK-2a & ++ & ++ & +++ & - & - & ++ & - & - & - \\
\hline RLF-3 & + & ++ & ++ & + & + & + & - & - & - \\
\hline RSoL-3 & ++ & ++ & +++ & + & + & + & - & - & - \\
\hline RSoFr-3 & ++ & ++ & +++ & + & + & + & - & - & - \\
\hline RUL-3 & ++ & ++ & ++ & + & + & + & - & - & - \\
\hline RUF-3 & ++ & ++ & ++ & + & + & ++ & - & - & - \\
\hline RSL-3 & ++ & ++ & +++ & ++ & + & ++ & - & - & + \\
\hline LC-3 & + & + & ++ & - & - & - & - & - & - \\
\hline PL-3 & ++ & ++ & ++ & - & ++ & ++ & - & + & + \\
\hline PK-3 & ++ & ++ & ++ & - & - & ++ & - & - & + \\
\hline PR-3 & ++ & ++ & ++ & - & - & ++ & - & - & + \\
\hline MP-3 & + & ++ & ++ & - & - & + & - & - & - \\
\hline AN-3 & ++ & ++ & ++ & - & - & + & - & - & - \\
\hline ANR-3 & ++ & ++ & ++ & + & ++ & + & ++ & ++ & + \\
\hline PCR-3 & - & - & ++ & + & + & ++ & - & - & - \\
\hline WL-3 & ++ & + & ++ & - & - & ++ & - & - & - \\
\hline $\mathrm{SC}-3$ & + & ++ & ++ & - & - & + & - & - & - \\
\hline SL-3 & - & + & ++ & - & ++ & ++ & - & - & + \\
\hline SLR-4b & + & - & ++ & ++ & ++ & ++ & - & + & ++ \\
\hline UD4a & - & - & + & - & - & - & - & - & - \\
\hline UD4b & - & - & ++ & - & - & ++ & - & - & ++ \\
\hline
\end{tabular}

For abbreviations see Table 1.

+: 1 active spot; ++: $2-3$ active spots; $+++: \geq 4$ spots. 
Rhododendron extracts, particularly RSoL-3, RSoFr-3, and RSL-3, exhibited very strong active spots in all three bioassays, as did Turkish Phlomis species. The total $\mathrm{MeOH}$ extract of the roots, as well as the water-solubles of the aerial parts of Scrophularia lepidota (SLR-4b and SL-3, respectively), efficiently scavenged the DPPH radical in all three polarity regions.

Table 4 illustrates the crude extracts that inhibited AChE on the developed TLC plate. All crude extracts showed one or more inhibition zones on the purple background. All hexane-solubles displayed at least one, but weakly active spots, in the high polarity $\left(\mathrm{R}_{\mathrm{f}} 0-0.33\right)$ and middle polarity $\left(\mathrm{R}_{\mathrm{f}}\right.$ $0.34-0.66)$ regions. RSoFr-1 was the only hexane extract that contained a big active spot with a very high $R_{f}$ value $\left(R_{f}\right.$ $0.9-0.97$ ). The purple color (vanillin $/ \mathrm{H}_{2} \mathrm{SO}_{4}$ ) and the broadness of this spot on TLC analysis indicated that it could be fat present in the fruits. ANR-1 was also found to be a potent AChE inhibitor, displaying five active spots in total.

The strongest $\mathrm{AChE}$ inhibitory potential was concentrated on the middle polarity extracts, namely the $\mathrm{CHCl}_{3} / \mathrm{CH}_{2} \mathrm{Cl}_{2}$-solubles. Except for SL-2a, all $\mathrm{CHCl}_{3} / \mathrm{CH}_{2} \mathrm{Cl}_{2}$ extracts appeared to possess AChE-inhibiting activity. In general, active spots were placed in the middle and low polarity regions. Particularly potent samples were RUL-2b, RPL-2a, and RSL- $2 b$ that furnished white spots whose intensities were comparable to galantamine $(2 \mu \mathrm{g} / \mathrm{spot})$ on the purple background. On the duplicate TLC plate sprayed with vanillin $/ \mathrm{H}_{2} \mathrm{SO}_{4}$ reagent, most of the active spots gave purple colors. Rhododendron species are well-known for contain-ing grayanatoxin (andromedotoxin)-type toxic diterpenes (Baytop, 1984), and the anti-AChE activity observed in this study might be due to these types of metabolites. Some extracts (RUL-2b, LC-2a, PL-2a, PK-2a, PR-2a, MP-2b, etc.), again, displayed active zones at the very top of the eluted TLC plate.

It proved to be difficult to evaluate the activity of most of the $\mathrm{H}_{2} \mathrm{O}$ extracts due to colorful chemicals (phenolics) present in these extracts. For example, catechin derivatives in Rhododendron species $\left(\mathrm{R}_{\mathrm{f}} 0-0.33\right)$, as determined by TLC comparison with (+)-catechin and (-)-epicatechin, reacted with the Fast Blue salt in the spray reagent to give orangebrown spots on TLC plate. Also, phenylpropanoids in Leonurus cardiaca L., Morina persica L., and three Phlomis species produced strong yellow spots on the purple background. Such zones were considered to be inactive in the current study. The most obvious enzyme inhibitory potential was detected in the water extract of the roots of Asperula nitida subsp. subcapitellata Sibth ex Sm (ANR-3) that produced active spots in all three polarity zones. The activity might be due to iridoid-type monoterpene glycosides or other terpenes that furnished purple to blue colors with vanillin $/ \mathrm{H}_{2} \mathrm{SO}_{4}$ reagent.

\section{Discussion}

Despite the wide availability of clinically useful antibiotics and semisynthetic derivatives, the search for new antimicro-
Table 4. Crude extracts inhibiting AChE enzyme.

\begin{tabular}{|c|c|c|c|}
\hline Extract & $\begin{array}{c}\mathrm{R}_{\mathrm{f}} \\
0-0.33\end{array}$ & $\begin{array}{c}\mathrm{R}_{\mathrm{f}} \\
0.34-0.66\end{array}$ & $\begin{array}{c}\mathrm{R}_{\mathrm{f}} \\
0.67-1.0\end{array}$ \\
\hline RPL-1 & ++ & - & - \\
\hline RLL-1 & + & - & - \\
\hline RSoL-1 & ++ & - & - \\
\hline RSoFr-1 & ++ & ++ & + \\
\hline RUL-1 & ++ & - & - \\
\hline RSL-1 & ++ & - & - \\
\hline LC-1 & ++ & + & - \\
\hline PL-1 & ++ & + & - \\
\hline PK-1 & ++ & + & - \\
\hline PR-1 & ++ & + & - \\
\hline MP-1 & ++ & + & - \\
\hline AN-1 & ++ & ++ & - \\
\hline ANR-1 & +++ & + & - \\
\hline PCR-1 & ++ & ++ & - \\
\hline WL-1 & + & + & - \\
\hline SC-1 & - & + & - \\
\hline SL-1 & - & + & - \\
\hline RPL-2a & - & +++ & ++ \\
\hline RPF-2b & - & + & + \\
\hline RLL-2b & - & + & ++ \\
\hline RLF-2b & - & ++ & ++ \\
\hline RSoL-2b & - & ++ & ++ \\
\hline RSoFr-2b & - & ++ & + \\
\hline RUL-2b & - & +++ & ++ \\
\hline RUF-2b & - & ++ & + \\
\hline RSL-2b & - & +++ & ++ \\
\hline $\mathrm{LC}-2 \mathrm{a}$ & - & - & + \\
\hline PL-2a & - & + & + \\
\hline PK-2a & - & ++ & + \\
\hline PR-2a & - & ++ & + \\
\hline MP-2b & - & + & ++ \\
\hline PCR-2a & + & - & ++ \\
\hline WL-2a & - & - & + \\
\hline SC-2a & + & - & - \\
\hline ANR-3 & + & ++ & ++ \\
\hline PCR-3 & - & ++ & + \\
\hline SLR-4b & - & - & ++ \\
\hline
\end{tabular}

For abbreviations see Table 1.

+: 1 active spot; ++: $2-3$ active spots; $+++: \geq 4$ spots.

bial agents, particularly those active toward resistant bacterial strains, is still an important field of medical investigation. Considering the enormous number and structural diversity of phytochemicals, it is obvious that the plant kingdom offers an enormous source for the discovery of systemic and/or locally active antimicrobial agents. There are different applications for the detection of antibiotic activity in crude plant extracts (Rios et al., 1988; Vanden Berghe \& Vlietinck, 1991). The agar-overlay method has widely been used for this purpose (Rahalison et al., 1991; Sánchez-Medina et al., 2001). In the current study, aimed at rapid screening of Turkish plants, this method quickly produced reproducible results. The data presented here indicated that a high per- 
centage of the plant extracts have a wide spectrum of antibacterial activity. Rhododendron extracts merit special mentioned here. Except for the RUF-2b, all $\mathrm{CHCl}_{3} / \mathrm{CH}_{2} \mathrm{Cl}_{2}$ extracts and more than half of the water extracts were active against all five Gram-positive bacteria, with the other half being active toward four Gram-positive strains. Antibiotic activity of some Rhododendron nectars has been attributed to the presence of acetylandromedol (Martini et al., 1990). The activity of the polar extracts, however, might be due to high contents of arbutin or similar hydroquinones as reported from several Rhododendron spp. (Akhtardzhiev, 1966; Shnyakina et al., 1981; Fan et al., 1999). To our knowledge, this is the first detailed antibacterial screening performed on this genus. The roots of Putoria calabrica provided the best antibacterial potential. Our previous studies on the aerial parts of this plant yielded iridoid, lignan, flavonoid, and anthraquinone type glycosides (Çalıs et al., 2001, 2002). The latter phenolic compounds are potentially responsible from such activity. The genus Asperula has also been reported to contain similar secondary metabolites (Sticher, 1971; Borisov \& Serbin, 1972; Borisov, 1975). Our current studies focusing on natural products with antibacterial activity in the roots of these two Rubiaceous plants are underway. Essential oils and crude extracts of several Phlomis spp. have shown antimicrobial activity (Ristic et al., 2000; Couladis et al., 2000). The antibiotic activity of two endemic Turkish Scrophularia spp. may be attributable to phenolic acids (Fernandez et al., 1996) or phenylethanoid glycosides (Çalıs et al., 1987, 1988). Our results seem to confirm the traditional use of the members of this genus. For the first time, a detailed antimicrobial study on Leonurus and Morina species are being reported in this study.

Oxidation is well-known to be the major cause of degradation and deterioration of lipids and foods. Interest in the search for new natural antioxidants has grown dramatically in the past decade since reactive oxygen species (ROS) production and oxidative stress were shown to be involved in the etiologies of diverse aging-related diseases. Antioxidants act by directly inhibiting the generation of the ROS, by directly scavenging the free radical, or by chelating metal ions. A large number of methods, both qualitative and quantitative, have been described in the literature for evaluation of antioxidant activity (Cuendet et al., 1997; Koleva et al., 2002). Owing to the complexity of the oxidation-antioxidation processes, no single method is capable of providing a comprehensive picture of the antioxidant profile of a sample of interest. Therefore, a multimethod approach has to be followed (Koleva et al., 2002). We used a combination of three simple but complementary methods for the qualitative detection of antioxidant/radical scavenging activities of Turkish plant extracts. Among these methods, DPPH appeared to be the most sensitive. This is a representative of the methods employing model radicals in the evaluation of radical scavengers and has successfully been used for the screening of large numbers of complex extracts and has provided a good basis for further isolation procedures (Cuendet et al., 1997;
Koleva et al., 2002). As mentioned before, the water extracts, particularly those obtained from Rhododendron spp., exhibited the prominent antioxidant and radical scavenging potential in all three assays. The activity of Rhododendron extracts appears to be due to the catechin derivatives and flavonoids (Hu et al., 1990; Chung et al., 1996). Also, the water-solubles of three Phlomis species showed considerably high activity, which is probably accountable to caffeic acid derivatives, such as phenylethanoid glycosides that are common for the members of this genus (Saracoglu et al., 1998; Kyriakopoulou et al., 2001). Water-solubles of the aerial parts of Scrophularia cryptophila (SL-3) and the crude EtOH extract of Scrophularia lepidota (SLR-4b) were found to possess strong radical scavenging and antioxidant properties. Phenylethanoid glycosides or ester iridoids, which are well-known for such activity (Cuendet et al., 1997; Heilmann et al., 2000), might be responsible from such potential.

Alzheimer disease (AD) is the most common cause of progressive cognitive dysfunction that results from a deficiency in cholinergic activity in brain. The symptoms of early stages of $\mathrm{AD}$ can be treated by AChE inhibitors. Several plant-derived drugs (rivastigmine, galantamine) inhibit AChE, hence increasing the endogenous levels of acetylcholine to boost cholinergic neurotransmission. Although plant alkaloids are best known for inhibiting AChE enzyme, recent studies indicate new classes of AChE-inhibiting phytochemicals, such as terpenoids, coumarins, and stilbene oligomers (Howes et al., 2003). In our study, we used a simple TLC method in combination with bioactivity staining for screening of a large number of plant extracts for their AChE-inhibitory potential. This method has been successfully applied to several Amaryllidaceae plant extracts (Marston et al., 2002), and worked well in our testing, particularly for apolar and middle polarity of extracts, and surprisingly indicated a high possibility of activity. We believe that many types of phytochemicals have remained uninvestigated for AChE inhibitory activity, and such potential might be greater than commonly thought. The preliminary TLC analyses presented here suggest that diverse classes of natural products might have AChE-inhibitory potential. However, this suggestion must still be proved with the isolated compounds. Antioxidants, such as vitamin E, have been reported to be useful in the treatment of AD (Zhou et al., 1996). Our future work will focus on possible correlations between antioxidant and AChE-inbitory activities of the pure isolates.

In conclusion, the data reported here show Turkish plants to possess a wide range of interesting activities. Further biological and chemical investigations on these plants are in progress.

\section{Acknowledgments}

We are grateful to Dr. Jörg Heilmann (ETH-Zurich) for allowing us to perform antimicrobial assays in his laboratory. 
The authors also thank Dr. Pinar Akbay (ETH-Zurich) and Dr. Christa Werner (University of Zurich) for their help in the antibacterial and $\mathrm{AChE}$ inhibition assays, respectively. This work was financially supported by the Swiss National Foundation and the Scientific and Technical Research Council of Turkey (TUBITAK/TBAG-2304).

\section{References}

Ahmad F, Rashid S, Bingöl S, Sener B (1993): Screening of some Turkish medicinal plants for their analgesic activities. J Faculty Pharm Gazi 10: 37-46.

Akhtardzhiev C (1966): Presence of arbutin and tannins in native representatives of the family Ericaceae. Pharmazie 21: 59-60.

Baytop T (1984): Therapy with Medicinal Plants in Turkey (Past and Present). Istanbul, Istanbul University Publications (in Turkish).

Borisov MI, Serbin AG (1972): Flavonoids of Asperula oppositifolia. Khim Prir Soedin 8: 122-123.

Borisov MI (1975): Anthraquinone glycosides of Asperula besseriana and Galium ruthenicum. Rastit Resur 11: 362-368.

Çalıs I, Gross GA, Sticher O (1987): Phenylpropanoid glycosides isolated from Scrophularia scopolii. Phytochemistry 26: 2057-2061.

Çalıs I, Gross GA, Sticher O (1988): Two phenylpropanoid glycosides from Scrophularia scopolii. Phytochemistry 27: 1465-1468.

Çalıs I, Heilmann J, Tasdemir D, Ireland CM, Sticher O (2001): Flavonoid, iridoid and lignan glycosides from Putoria calabrica. J Nat Prod 66: 961-964.

Çalıs I, Tasdemir D, Ireland CM, Sticher O (2002): Lucidin type anthraquinone glycosides from Putoria calabrica. Chem Pharm Bull 50: 701-702.

Chung TY, Kim MA, Jones AD (1996): Antioxidative activity of flavonoids isolated from Jindalrae flowers (Rhododendron mucronulatum Turcz.). Han'guk Nonghwa Hakhoechi 39: 320-326. Chem Ab 126: 100383.

Claeson P, Bohlin L (1997): Some aspects of bioassay methods in natural-product research aimed at drug lead discovery. Trends Biotechnol 155: 245-248.

Couladis M, Tanimanidis A, Tzakou O, Chinou IB, Harvala C (2000): Essential oil of Phlomis lanata growing in Greece: chemical composition and antimicrobial activity. Planta Med 66: 670-672.

Cuendet M, Hostettmann K, Potterat O, Dyatmiko W (1997): Iridoid glucosides with free radical scavenging properties from Fagraea blumei. Helv Chim Acta 80: 1144-1152.

Davis PH (1965-1988): Flora of Turkey and the East Aegean Islands, Vols. 1-10. Edinburgh, Edinburgh University Press.

Dönmez AA (2002): Wendlandia ligustroides (Rubiaceae): a new genus for the flora of Turkey. The Karaca Arb Mag 6: $147-156$.

Fan CQ, Yang GJ, Zhao WM, Ding BY, Qin GW (1999): Chemical studies on Ericaceae plants. Part 5. Phenolic compo- nents from Rhododendron latoucheae. Chinese Chem Lett 10: 567-570.

Fernandez MA, Garcia MD, Saenz MT (1996): Antibacterial activity of phenolic acid fractions of Scrophularia frutescens and Scrophularia sambucifolia. J Ethnopharmacol 53: 11-14.

Güner A, Özhatay N, Ekim T, Baser KHC (2000): Flora of Turkey and The East Aegean Islands, Vol. 11. Edinburgh, Edinburgh University Press.

Hamburger M, Hostettmann K (1991): Bioactivity in plants: The link between phytochemistry and medicine. Phytochemistry 30: 3864-3874.

Heilmann J, Çalıs I, Kırmızıbekmez H, Schühly W, Harput S, Sticher O (2000): Radical scavenger activity of phenylethanoid glycosides in FMLP stimulated human polymorphonuclear leucocytes: structure-activity relationships. Planta Med 66: 746-748.

Honda G, Yesilada E, Tabata M, Sezik E, Fujita T, Takeda Y, Takaishi Y, Tanaka T (1996): Traditional medicine in Turkey. VI. Folk medicine in west Anatolia: Afyon, Kütahya, Denizli, Mugla, Aydın provinces. J Ethnopharmacol 53: 75-87.

Howes MJR, Perry NSL, Houghton PJ (2003): Plants with traditional uses and activities, relevant to the management of Alzheimer's disease and other cognitive disorders. Phytother Res 17: 1-18.

Hu M, Liu Y, Xiao P (1990): The chemical constituents of Rhododendron wiltonii. Zhiwu Xuebao 32: 777-782. 114: 160773.

Jayasinghe ULB, Jayasooriya CP, Bandara BMR, Ekanayake SP, Merlini L, Assante G (2002): Antimicrobial activity of some Sri Lankan Rubiaceae and Meliaceae. Fitoterapia 73: 424-427.

Koçak S, Özhatay N (2000): Local names of some plants from Karaman province. J Fac Pharm Istanbul 33: 2735.

Koleva II, van Beek TA, Linssen JPH, de Groot A, Evstatieva LN (2002): Screening of plant extracts for antioxidant activity: A comparative study on three testing methods. Phytochem Anal 13: 8-17.

Kupchan SM, Britton RW, Ziegler MF, Sigel CW (1973): Bruceantin, a new potent antileukemic simaroubolide from Brucea antidysenterica. J Org Chem 38: 178-179.

Kyriakopoulou I, Magiatis P, Skaltsounis AL, Aligiannis N, Harvala C (2001): Samisoide, a new phenylethanoid glycoside with free-radical scavenging and antimicrobial activities from Phlomis samia. J Nat Prod 64: 10951097.

Marston A, Kissling J, Hostettmann K (2002): A rapid TLC bioautographic method for the detection of acetylcholinesterase and butyrylcholinesterase inhibitors in plants. Phytochem Anal 13: 51-54.

Martini M, Schmid A, Hess D (1990): Antibiotics, sugars and aminoacids in nectar of Rhododendron and Pipthanthus species from Nepal. Bot Acta 103: 343-348.

Onat FY, Yegen BC, Lawrence R, Oktay A, Oktay S (1991): Mad honey poisoning in man and rat. Rev Environ Health 9: 3-9. 
Rahalison L, Hamburger M, Hostettmann K, Monod M, Frenk E (1991): A bioautographic agar overlay method for the detection of antifungal compounds from higher plants. Phytochem Anal 2: 199-203.

Rios JL, Recia MC, Villar A (1988): Screening methods for natural products with antimicrobial activity, a review of the literature. J Ethnopharmacol 23: 127-149.

Ristic MD, Duletic-Lausevic S, Knezevic-Vukcevic J, Marin PD, Simic D, Vukojevic J, Janackovic P, Vajs V (2000): Antimicrobial activity of essential oils and ethanol extract of Phlomis fruticosa L. (Lamiaceae). Phytother Res 14: 267-271.

Sánchez-Medina A, García-Sosa K, May-Pat F, Peña-Rodríguez LM (2001): Evaluation of biological activity of crude extracts from plants used in Yucatecan traditional medicine Part I. Antioxidant, antimicrobial and $\beta$-glucosidase inhibition activities. Phytomedicine 8: 144-151.

Saracoglu I., Kojima K, Harput US, Ogihara Y (1998): A new phenylethanoid glycoside from Phlomis pungens Willd. var. pungens. Chem Pharm Bull 46: 726-727.

Sener B (1994): Recent results in the search for bioactive compounds from Turkish medicinal plants. Pure Appl Chem 66: 2295-2298.

Sezik E, Tabata M, Yesilada E, Honda G, Goto K, Ikeshiro Y (1991): Traditional medicine in Turkey. I. Folk medicine in north-east Anatolia. J Ethnopharmacol 35: 191-196.

Sezik E, Yesilada E, Honda G, Takaishi Y, Takeda Y, Tanaka T (2001): Traditional medicine in Turkey. X. Folk medicine in central Anatolia. J Ethnopharmacol 75: 95-115.

Shnyakina GP, Sedelnikova VA, Tsygankova NB (1981): Arbutin content in the leaves of some plants grown at Dal'nyi Vostok. Rastit Resur 17: 568-571.
Sökmen A, Jones BM, Ertürk M (1999): The in vitro antibacterial activity of Turkish medicinal plants. J Ethnopharmacol 67: 79-86.

Sticher O (1971): Isolation of monotropein from Asperula odorata. Pharm Acta Helv 46: 121-128.

Sütlüpınar N, Mat A, Satganoglu Y (1993): Poisoning by toxic honey in Turkey. Arch Toxicol 67: 148-150.

Tuzlacı E, Aymaz PE (2001): Turkish folk medicinal plants. Part IV: Gönen (Ballkesir). Fitoterapia 72: 323-343.

Vanden Berghe DA, Vlietinck AJ (1991): Screening methods for antibacterial and antiviral agents from higher plants. In: Hostettmann K, ed., Methods in Plant Biochemistry, Assays for Bioactivity, Vol. 6. London, Academic Press, pp. 4769.

Whittern CC, Miller EE, Pratt DE (1984): Cottonseed flavonoids as lipid antioxidants. J Am Oil Chem Soc 61: 1075-1078.

Yesilada E, Honda G, Sezik E, Tabata M, Fujita T, Tanaka T, Takeda Y, Takaishi Y (1995): Traditional medicine in Turkey. V. Folk medicine in the inner Taurus mountains. $J$ Ethnopharmacol 46: 133-152.

Yesilada E, Sezik E, Honda G, Takaishi Y, Takeda Y, Tanaka T (1999): Traditional medicine in Turkey. IX. Folk medicine in north-west Anatolia. J Ethnopharmacol 64: 195-210.

Yesilada E (2002): Biodiversity in Turkish folk medicine. In: Sener B, ed., Biodiversity: Biomolecular Aspects of Diversity and Innovative Utilization. London, Kluwer Academic/Plenum Publishers, pp. 119-135.

Zhou Y, Gopalakrishnan V, Richardson JS (1996): Actions of neurotoxic beta-amyloid on calcium homeostasis and viability of PC12 cells are blocked by antioxidants but not calcium channel antagonists. $J$ Neurochem 67: 14191425. 